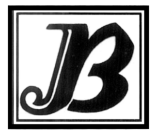

J. Bio-Sci. 29(2): 111-122, 2021 (December)

ISSN 1023-8654

http://www.banglajol.info/index.php/JBS/index

DOI: https://doi.org/10.3329/jbs.v29i2.54960

\title{
EFFECTS OF OSMOTIC, THERMAL AND PLANT GROWTH REGULATORS SEED PRIMING ON DIFFERENT WHEAT VARIETIES
}

\author{
MGU Ahmed", F Khatun and Z Islam \\ Dept. of Agronomy and Agricultural Extension, University of Rajshahi, Rajshahi-6205, Bangladesh
}

\begin{abstract}
Proper germination and proper growth of seedlings in conventional farming methods are often not achieved at the desired rate. The purpose of priming is to reduce germination time and improve stand and percentage of germination and increases vigour for fast and strong plant development. In order to evaluate the effect of seed priming on growth and yield of wheat the present study was conducted at Agronomy Farm House, Rajshahi University. Three wheat varieties (BARI Gom-24, BARI Gom-25 and BARI Gom-26) were tested with three groups of priming media (osmo-priming, thermos-priming and plant growth regulator priming) and control (non-soaked). Seeds were primed for $24 \mathrm{~h}$ at $25^{\circ} \mathrm{C}$ with four priming media, osmo-priming ( $1 \% \mathrm{NaCl}, 2 \% \mathrm{KNO}_{3}, 2 \% \mathrm{KH}_{2} \mathrm{PO}_{4}$, and $10 \%$ PEG), PEG-Priming $(50 \mu \mathrm{M}$ $\mathrm{GA}_{3}$ and $\left.50 \mu \mathrm{M} \mathrm{BAP}\right)$ and thermo-priming $\left(0^{\circ} \mathrm{C}, 5^{\circ} \mathrm{C}\right.$ and $\left.10^{\circ} \mathrm{C}\right)$ and control was without priming agent. All types of priming media were significantly different among their types for plant height $(\mathrm{cm})$, tiller number and dry biomass (g). PEG was significantly different in osmo-priming, $\mathrm{GA}_{3}$ was significantly different in PGR-priming and $0^{\circ} \mathrm{C}$ was significantly different in thermo-priming. In case of vigor index, $2 \%$ $\mathrm{KH}_{2} \mathrm{PO}_{4}$ was suitable among osmo-priming, $\mathrm{GA}_{3}$ was better than BAP priming and $0^{\circ} \mathrm{C}$ was optimum among all temperature priming. Seed priming helps seeds to grow rapidly and evenly in the field, producing healthier and faster maturing crops with better yields.
\end{abstract}

Key words: Osmo-priming, PGR priming, Seed, Thermo-priming, Wheat

\section{Introduction}

Priming in botany and agriculture is a form of seed planting preparation in which the seeds are pre-soaked before planting. Priming is not an extremely widely-used method. In general, most kinds of seeds experimented with so far have shown an overall advantage over seeds that are not primed. Many worker have shown a faster emergence time (the time it takes for seeds to rise above the surface of the soil), a higher emergence rate (the number of seeds that make it to the surface), and better growth, suggesting that the head-start helps them get a good root system down early and grow faster. This method can be useful to farmers because it saves them the money and time spent for fertilizers, re-seeding, and weak plants.

Seed priming has presented promising, and even surprising results, for many crop seeds (Bradford 1986). Priming in its traditional sense, soaking of seeds in water before sowing, has been the experience of farmers in India in an attempt to improve crop stand establishment but the practice was without the knowledge of the safe limit of soaking duration (Harris 1996). Moreover, Harris et al. (1999), promoted a low cost, low risk technology called 'on-farm seed priming' that would be appropriate for all farmers, irrespective of their socioeconomic

*Author for correspondence: ahmedmgu@ru.ac.bd 
status. On-farm seed priming involves soaking the seed in water, surface drying and sowing the same day. The rationale is that sowing soaked seed decrease the time needed for germination and allow the seedling to escape deteriorating soil physical conditions. According to Khan (1992), osmotic conditioning in its modern sense, aims to reduce the time of seedling emergence, as well as synchronize and improve the germination percentage, by subjecting the seeds to a certain period of imbibition using osmotic solutions. The seeds normally begin water uptake on contact with this solution and stop the process as soon as they become balanced with the water potential of the solution.

The benefits of seed priming in all crops included, faster emergence, more and uniform stands, less need to re-sow, more vigorous plants, drought tolerance, earlier flowering, earlier harvest maturity and higher seed yield. The beneficial effect of these seed priming treatments were reflected in greater cellular membrane integrity, counter action of lipid peroxidation and free radical chain reaction often found to be directly correlated with the maintenance of viability and reduced moisture uptake by hydrated dehydrated seed (Dollypan and Basu 1985), antipathogenic effects (Powell and Mathews 1986), repair of biochemical lesions by the cellular enzymatic repair system and metabolic removal of toxic substances and counteraction of free radical and lipid peroxidation reactions .

Therefore, availability of quality seed to the farmer at an affordable price and in time is considered crucial for enhancing and sustaining the agricultural productivity. The production of quality seed and maintenance of high seed germination is of utmost importance in a seed programme. Seeds are practically worthless if upon planting they fail to germinate and are not able to give adequate plant stand in the field in addition to healthy and vigorous plants. Seed technologists and seeds producers are therefore confronted mainly with two challenges maintaining the viability and vigour of seeds in storage. Secondly, exploring the utility of low quality carry over seeds, the vigour and viability of seeds in storage can be maintained over long periods by controlling storage environment. Rapid germination and emergence is an important determinant of successful establishment (Heydecker et al. 1973 \& 1975). Harris et al. (1999) reported seed priming as one of the most important developments to help rapid and uniform germination and emergence of seeds and to increase seed tolerance to adverse environmental conditions. However, the information on these aspects is scanty. Hence, the present investigation on the effect of seed priming on germination and field performance in wheat seeds was initiated to determine the response of wheat to three types priming treatment and to standardize the priming agent for growth and yield of wheat.

\section{Materials and Methods}

\section{Plant materials and land preparation}

The present work was carried out at Agronomy Farm House, Department of Agronomy and Agricultural Extension, University of Rajshahi during the Rabi season (winter). The three wheat varieties developed by Bangladesh Agricultural Research Institute (BARI) were BARI Gom-24 (Prodip), BARI Gom-25 and BARI Gom-26 was used in this study. Seeds of designated wheat varieties were collected from Regional Wheat Research Center, Shayampur, Rajshahi. All fertilizer except urea was applied with following recommended dose during final land preparation; TSP $180 \mathrm{~kg} / \mathrm{ha}$, MoP $50 \mathrm{~kg} / \mathrm{ha}$ and zypsum $120 \mathrm{~kg} / \mathrm{ha}$. Urea (220 kg/ha) was applied in three splits just after application of irrigation. 


\section{Seed priming with priming materials}

\section{Osmo-priming}

In this case each solution was prepared in a separate container. Aqueous solution of $1 \% \mathrm{NaCl}, 2 \% \mathrm{KNO}_{3}$, $2 \% \mathrm{KH}_{2} \mathrm{PO}_{4}$ and $10 \%$ PEG (polyethylene glycol) were kept at $25^{\circ} \mathrm{C}$ temperature for $24 \mathrm{~h}$. Then the seeds were washed individually three times with ordinary tap water. Mature seeds were dried at room temperature for several hours before sowing.

\section{Thermo-priming}

The seeds were kept in incubators and maintain in a laboratory at temperatures of $0^{\circ} \mathrm{C}, 5^{\circ} \mathrm{C}$ and $10^{\circ} \mathrm{C}$ for one day and night before sowing. About $60 \%$ humidity was maintained in each container to continue the moisture content of the blotting paper. The seeds were then kept at normal room temperature for a few hours and then sown in the growing field.

\section{PGR-Priming}

Plant growth regulators are dissolved in 95\% ethanol in the first stage of preparation and then dissolved in water as a priming agent. The seeds are soaked in aqueous solution of $50 \mu \mathrm{M} \mathrm{GA}$ (gibberellic acid), and 50 $\mu \mathrm{M}$ BAP (6-benzylaminopurine) for $24 \mathrm{~h}$ at $25^{\circ} \mathrm{C}$. After that the growth regulators are removed by washing with tap water at least 3 times. The surface was then dried for a few hours at room temperature and prepared for sowing. The experiment consisted of 15, 12 and 9 plots (included 3 replications) for osmo-priming, thermos-priming and PGR-priming respectively. The size of each plot was $2 \mathrm{~m}^{2}$.

\section{Data recording and harvesting}

During the cultivation of wheat crop, several cultural practices including irrigation, weeding and pest management were applied where applicable. Data on germination, growth and development were collected in the first two weeks after sowing and some data were recorded after 30, 45, 60, 75 days after sowing (DAS) and postharvest period. The daily record of germination of seeds were kept starting from first day up to $10^{\text {th }}$ day after placement of seeds for germination. Seed vigor index (SVI) was calculated by determining the germination percentage and seedling length of the same seed lot (Gupta 1993). Vigour index was calculated by the following formula.

\section{Vigour Index}

$$
\begin{aligned}
& =\frac{\text { Number of seed germination at first count }}{\text { Days required at first count }} \\
& +\frac{\text { Number of seed germination at last count }}{\text { Days required at last count }}
\end{aligned}
$$

Plant height, tiller number, dry biomass and yield of wheat were also collected. All experimental data were subjected to analysis of variance (ANOVA) using IBM SPSS Statistics, version 22. Mean values were compared by the Duncan's multiple range test (DMRT) (Gomez and Gomez 1984) at the 5\% level. 


\section{Results and Discussion}

\section{Seed vigor index}

Seed vigor is a quality parameter which needs to be assessed to supplement germination and viability tests to gain insight into the performance of a seed lot in the field. Osmo-priming had significant variation in terms of vigor index of three wheat varieties. The highest vigor index was recorded in $\mathrm{KH}_{2} \mathrm{PO}_{4}$ for BARI Gom-25 and the lowest vigor index was found in control plot of wheat varieties (Fig. 1). Among the three wheat varieties, seed vigor of BARI Gom-25 was optimum for most of osmo-priming. In case of thermo-priming, BARI Gom-24 showed maximum seedling with vigorous growth rate among the tested three varieties. The vigor index was affected mildly with the change of temperature. Less seeding was found for BARI Gom-26 in thermopriming. Plant growth regulators slightly influenced the seedling vigorously for most of the wheat varieties. BARI Gom-24 was produced most vigorous seedling using gibberellic acid $\left(\mathrm{GA}_{3}\right)$. Overall all the use of different priming agents, BARI Gom-24 and BARI Gom-25 varieties produced highly vigor saplings. On the other hand, BARI Gom-26 varieties had been affected less.

As the seedling level vigorously test was conducted in an optimum condition specific to different species. Growth tests are based on the principle that vigorous seeds grow at a faster rate than poor vigor seeds even under favorable environments. Vigorous seeds rapidly germinate, metabolize and establish in the field. Therefore, any method used to determine the rapidity of growth of the seedling was gave an indication of seed vigor level (Gupta 1993). Osmotically primed tomato seeds showed improved stand establishment, early seedling growth and yield, seedlings from primed seeds emerged earlier and more uniformly than seedlings from untreated seeds (Farook et al. 2005). Priming techniques has been reported to help in dormancy breakdown in many vegetable crops including tomato (Bradford 1986, Liu et al. 1996, Kester et al. 1997).

\section{Plant height (cm)}

Osmo-priming had significant influence on plant height (cm) of BARI Gom-24 and BARI Gom-26. Only plant height of BARI Gom-25 resulted maximum but it was non-significant statistically using osmo-priming (Table 1). There was significantly different plant height of BARI Gom-24 were recorded using NaCl. In case of BARI Gom-26, there was significantly different plant height was found using $\mathrm{KH}_{2} \mathrm{PO}_{4}$ among osmo-priming types. Thermo-priming had significant influence to produce taller wheat for BARI Gom-25 and BARI Gom-26 except BARI Gom-24. Among the different temperature, lowest temperature $\left(0^{\circ} \mathrm{C}\right)$ was induced significantly highest plant height for all wheat varieties. Plant growth regulators also had significant role to produce taller wheat plant for BARI Gom-25 and BARI Gom-26. BARI Gom-24 gave the lowest plant height among the PGR, BAP had influenced on plant height of all wheat varieties. The conventional wheat plants were smaller in size than the seed priming plants (Fig. 2). Among the priming methods, the use of high temperature $\left(10^{\circ} \mathrm{C}\right)$ did not give good results.

In addition to better establishment, farmers reported that primed crops grew more vigorously, earlier and yielded higher (Farooq et al. 2008). It has also been reported that seed priming improves emergence, stand establishment, tillering, and straw yields, (Farooq et al. 2008). Potassium hydro phosphate $\left(\mathrm{K}_{2} \mathrm{HPO}_{4}\right)$, polyethylene glycol $\left(\mathrm{PEG}_{6000}\right.$ ) (Aquila and Taranto 1986) have been introduced as the osmoticum which have shown good potential to enhance emergence and growth of wheat. Water has also been used successfully as a seed priming medium for wheat (Harris et al. 2001). Crops by seed priming increased in growth rate were reported by Singh et al. (2015). 


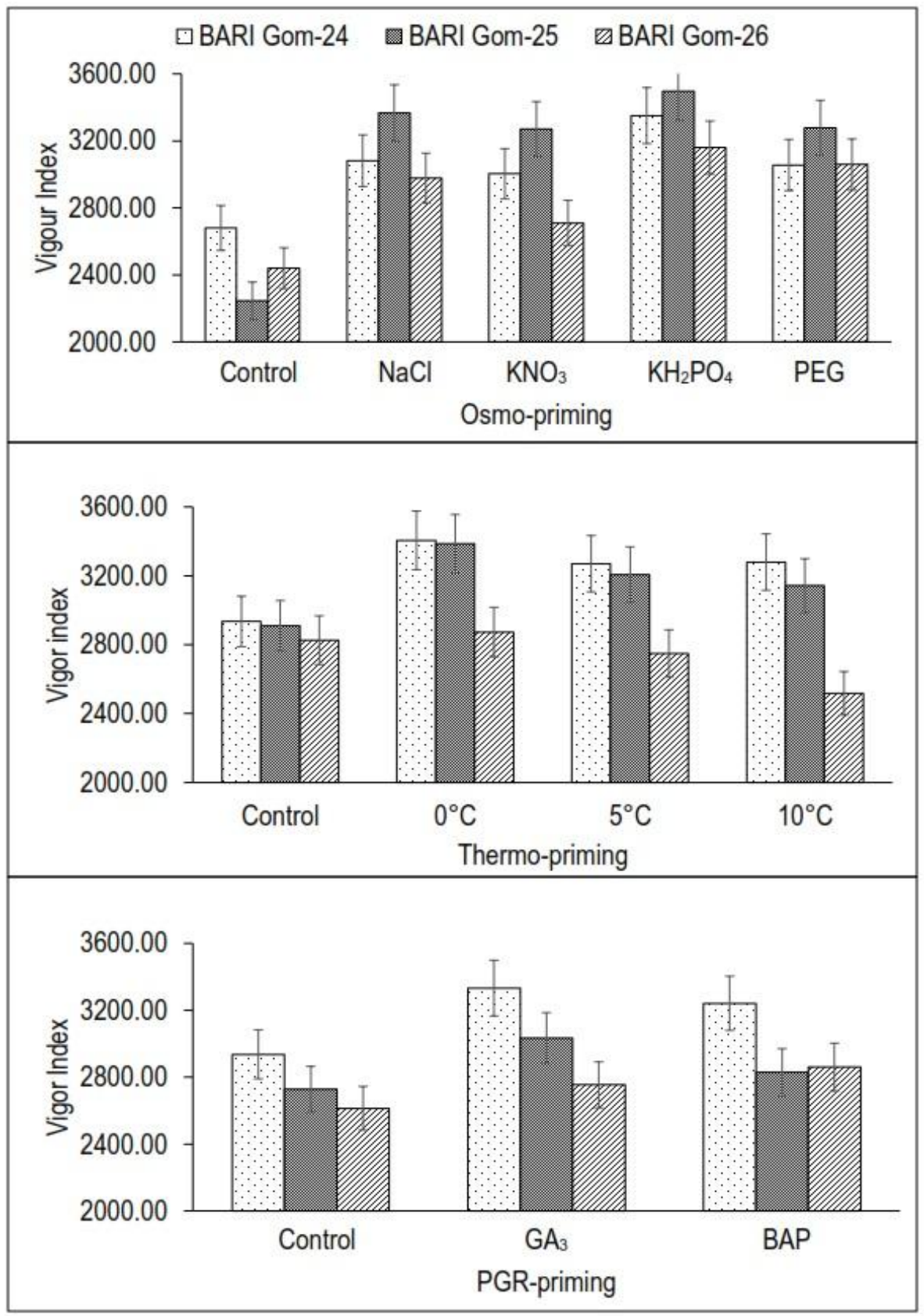

Fig. 1: Influence of different priming agent (osmo-priming, thermo-priming and PGR-priming) on vigor index of three wheat varieties. 
Table 1. Effect of priming agents on plant height $(\mathrm{cm})$ of three wheat varieties

\begin{tabular}{lllll}
\hline Priming types & Seed priming & BARI Gom-24 & BARI Gom-25 & BARI Gom-26 \\
\hline \multirow{5}{*}{ Osmo-priming } & Control & $94.33 \pm 0.56 \mathrm{ab}^{\star}$ & $97.03 \pm 0.57 \mathrm{~ns} \mathrm{n}^{\star \star}$ & $94.83 \pm 0.38 \mathrm{bc}$ \\
& $\mathrm{NaCl}$ & $95.96 \pm 0.56 \mathrm{ab}$ & $98.76 \pm 0.57 \mathrm{~ns}$ & $95.20 \pm 0.38 \mathrm{abc}$ \\
& $\mathrm{KNO}_{3}$ & $94.46 \pm 0.56 \mathrm{ab}$ & $98.03 \pm 0.57 \mathrm{~ns}$ & $95.36 \pm 0.38 \mathrm{abc}$ \\
& $\mathrm{KH}_{2} \mathrm{PO}_{4}$ & $93.80 \pm 0.56 \mathrm{~b}$ & $98.13 \pm 0.57 \mathrm{~ns}$ & $95.83 \pm 0.38 \mathrm{ab}$ \\
& $\mathrm{PEG}$ & $95.63 \pm 0.56 \mathrm{ab}$ & $98.40 \pm 0.57 \mathrm{~ns}$ & $94.43 \pm 0.38 \mathrm{c}$ \\
\hline \multirow{5}{*}{ Thermo-priming } & $\mathrm{Control}$ & $94.93 \pm 0.735 \mathrm{~ns}$ & $95.06 \pm 0.240 \mathrm{~b}$ & $94.20 \pm 0.403 \mathrm{~b}$ \\
& $0^{\circ} \mathrm{C}$ & $95.90 \pm 0.735 \mathrm{~ns}$ & $96.16 \pm 0.240 \mathrm{a}$ & $95.63 \pm 0.403 \mathrm{a}$ \\
& $5^{\circ} \mathrm{C}$ & $94.86 \pm 0.735 \mathrm{~ns}$ & $94.53 \pm 0.240 \mathrm{~b}$ & $94.50 \pm 0.403 \mathrm{~b}$ \\
& $10^{\circ} \mathrm{C}$ & $94.70 \pm 0.735 \mathrm{~ns}$ & $94.96 \pm 0.240 \mathrm{~b}$ & $95.06 \pm 0.403 \mathrm{ab}$ \\
\hline \multirow{5}{*}{ PGR-priming } & $\mathrm{Control}$ & $94.93 \pm 0.493 \mathrm{~ns}$ & $95.06 \pm 0.203 \mathrm{ab}$ & $94.20 \pm 0.184 \mathrm{c}$ \\
& $\mathrm{GA} 3$ & $94.73 \pm 0.493 \mathrm{~ns}$ & $95.56 \pm 0.203 \mathrm{a}$ & $96.03 \pm 0.184 \mathrm{~b}$ \\
& $\mathrm{BAP}$ & $96.17 \pm 0.493 \mathrm{~ns}$ & $94.63 \pm 0.203 \mathrm{~b}$ & $97.10 \pm 0.184 \mathrm{a}$ \\
\hline
\end{tabular}

* In a column, data are the mean values with standard error having different letters within six different treatments differ significantly as per LSD at $5 \%$ level. ${ }^{* \star} n s=$ Non-Significant. Data was recorded at 60 days after sowing.

Table 2. Influence of different priming agents on tiller number of three wheat varieties

\begin{tabular}{lllll}
\hline Priming types & Seed priming & BARI Gom-24 & BARI Gom-25 & BARI Gom-26 \\
\hline \multirow{5}{*}{ Osmo-priming } & Control & $3.00 \pm 0.49 \mathrm{c}$ & $3.00 \pm 0.49 \mathrm{c}$ & $3.10 \pm 0.49 \mathrm{c}$ \\
& $\mathrm{NaCl}$ & $4.07 \pm 0.49 \mathrm{~b}$ & $4.07 \pm 0.49 \mathrm{~b}$ & $4.57 \pm 0.49 \mathrm{~b}$ \\
& $\mathrm{KNO}_{3}$ & $4.03 \pm 0.49 \mathrm{~b}$ & $4.03 \pm 0.45 \mathrm{~b}$ & $4.23 \pm 0.49 \mathrm{~b}$ \\
& $\mathrm{KH}_{2} \mathrm{PO}_{4}$ & $4.00 \pm 0.49 \mathrm{~b}$ & $4.00 \pm 0.49 \mathrm{~b}$ & $4.00 \pm 0.49 \mathrm{~b}$ \\
& $\mathrm{PEG}$ & $5.07 \pm 0.49 \mathrm{a}$ & $5.67 \pm 0.49 \mathrm{a}$ & $5.07 \pm 0.49 \mathrm{a}$ \\
\hline \multirow{5}{*}{ Thermo-priming } & $\mathrm{Control}$ & $3.00 \pm 0.41 \mathrm{c}$ & $3.00 \pm 0.50 \mathrm{~b}$ & $3.00 \pm 0.33 \mathrm{~b}$ \\
& $0^{\circ} \mathrm{C}$ & $5.13 \pm 0.41 \mathrm{a}$ & $4.67 \pm 0.50 \mathrm{a}$ & $4.37 \pm 0.33 \mathrm{a}$ \\
& $5^{\circ} \mathrm{C}$ & $4.33 \pm 0.41 \mathrm{~b}$ & $3.17 \pm 0.50 \mathrm{a}$ & $3.70 \pm 0.33 \mathrm{~b}$ \\
& $10^{\circ} \mathrm{C}$ & $4.00 \pm 0.41 \mathrm{~b}$ & $3.13 \pm 0.50 \mathrm{a}$ & $3.33 \pm 0.33 \mathrm{~b}$ \\
\hline \multirow{5}{*}{ PGR-priming } & $\mathrm{Control}$ & $3.20 \pm 0.47 \mathrm{c}$ & $3.10 \pm 0.50 \mathrm{~b}$ & $3.00 \pm 0.37 \mathrm{~b}$ \\
& $\mathrm{GA}$ & $5.12 \pm 0.47 \mathrm{a}$ & $4.71 \pm 0.50 \mathrm{a}$ & $4.35 \pm 0.37 \mathrm{a}$ \\
& $\mathrm{BAP}$ & $4.33 \pm 0.47 \mathrm{~b}$ & $3.16 \pm 0.50 \mathrm{a}$ & $3.74 \pm 0.37 \mathrm{~b}$ \\
\hline
\end{tabular}

In a column, data are the mean values with standard error having different letters within six different treatments differ significantly as per LSD at $5 \%$ level, ${ }^{*} n s=$ Non-Significant. Data was recorded at 90 days after sowing. 


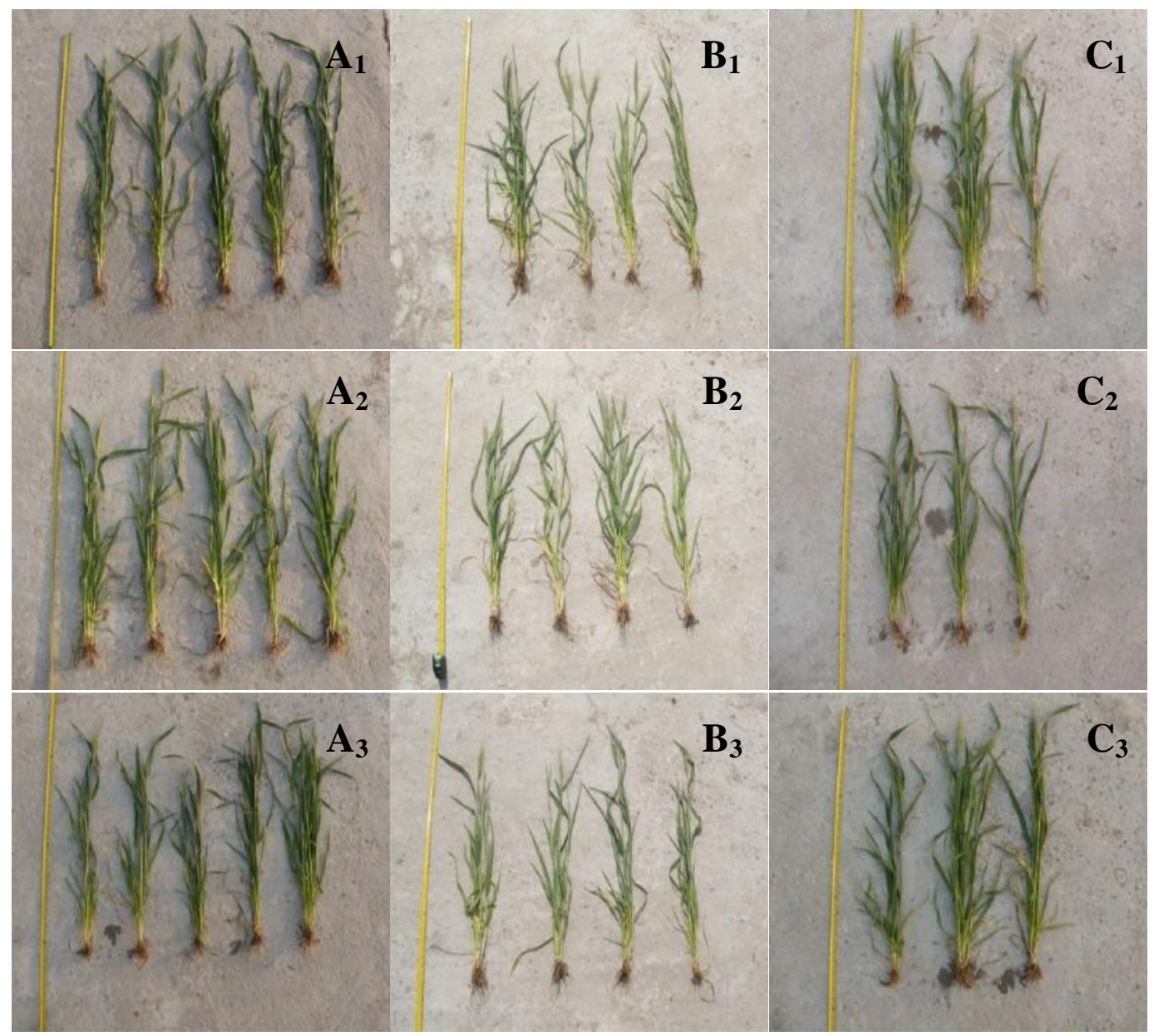

Fig. $2\left(A_{1}-A_{3}, B_{1}-B_{3}\right.$ and $\left.C_{1}-C_{3}\right)$ : Role of different seed priming types on plant height using three wheat varieties. $\mathrm{A}_{1}-\mathrm{A}_{3}=$ osmo-priming agents respectively control, $\mathrm{NaCl}, \mathrm{KNO}_{3}, \mathrm{H}_{2} \mathrm{SO}_{4}, \mathrm{PEG}$ (left to right). $\mathrm{B}_{1}-\mathrm{B}_{3}=$ thermo-priming agents gradually control, $0^{\circ} \mathrm{C}, 5^{\circ} \mathrm{C}, 10^{\circ} \mathrm{C}$ (left to right). $\mathrm{C}_{1}-\mathrm{C}_{3}=$ plant growth regulators (PEG)priming agents respectively control, $\mathrm{GA}_{3}, \mathrm{BAP}$ (left to right). $\mathrm{A}_{1}-\mathrm{C}_{1}=\mathrm{BARI}$ Gom-24, $\mathrm{A}_{2}-\mathrm{C}_{2}=\mathrm{BARI}$ Gom-25 and $\mathrm{A}_{3}-\mathrm{C}_{3}=\mathrm{BARI}$ Gom-26. Photographs were taken at 60 days after sowing.

\section{Tiller number}

Osmo-priming had a significant effect in terms of tiller number of three wheat varieties. The highest tiller number (5.67) was recorded in PEG at 60 DAS from BARI Gom-24 and the lowest tiller number (3.0) was found in control plot had no priming (Table 2). Temperature had significant effect on tiller number of three wheat varieties. Different temperature $\left(0^{\circ} \mathrm{C}, 5^{\circ} \mathrm{C}\right.$ and $\left.10^{\circ} \mathrm{C}\right)$ shows different tiller number at three sampling dates. The significant maximum tiller number (5.13) was recorded in $0^{\circ} \mathrm{C}$ temperatures from BARI Gom-24 and the lowest tiller number was found for thermo-priming (Table 2) for all wheat varieties. PGR (plant growth 
regulators) priming materials had significant effect on tiller number of three wheat varieties. The significantly highest tiller number (5.12) was recorded in $\mathrm{GA}_{3}$ from all wheat varieties and the lowest tiller number (3.0) was found in control. Low temperature and $\mathrm{GA}_{3}$ induced seeds have been instrumental in increasing the number of tillers. Of the three types of priming, osmo-priming has increased the tiller number of all varieties of wheat.

Number of tiller was significantly affected by seed priming, increased nitrogen fertilizer and high moisture level in rice (Imranuddin et al. 2016). Seed treated with nutrients has positive effects on the performance of wheat because it improves emergence, tiller/ $\mathrm{m}^{-2}$ and also brings chemical changes in the endosperm due to activation of enzymes (Rowse 1995). Higher number of tillers $\mathrm{m}^{-2}$ was recorded for $\mathrm{P}$ primed seed contrast to water soaked and dry seed. Similar views by Singh et al. (1998) who reported that number of tillers $\mathrm{m}^{-2}$ increased with increasing number of irrigation from two to four. Likewise, Akram (2000) reported that high levels of $\mathrm{N}$ application stimulated tillers $\mathrm{m}^{-2}$ in barley. The increase in tillers due to priming might due to improved emergence and seedling growth in the plots of primed seed (Harris et al. 2000).

\section{Dry biomass (g/plant)}

Osmo-priming showed significant variation in terms of dry biomass of three wheat varieties. The highest dry weight (10.68 g/plant) was recorded in PEG for BARI Gom-26 and the lowest dry weight ( $7.48 \mathrm{~g} /$ plant) was found in control plot which had no priming for BARI Gom-24 (Table 3). Different temperature $\left(0^{\circ} \mathrm{C}, 5^{\circ} \mathrm{C}\right.$ and $10^{\circ} \mathrm{C}$ ) for seed priming had significant effect on dry biomass of three wheat varieties. The highest dry biomass (9.11 g/plant) was recorded in $5^{\circ} \mathrm{C}$ temperatures for BARI Gom-25 and the lowest dry weight $(7.5$ $\mathrm{g} /$ plant) was found control plot had no priming in BARI Gom-24. PGR (plant growth regulators) priming material (BAP, $\mathrm{GA}_{3}$ ) had significant effect on dry biomass of three wheat varieties. The maximum dry weight (9.53 $\mathrm{g} /$ plant) was recorded in $\mathrm{GA}_{3}$ from BARI Gom-25 and the lowest dry weight (7.5 g/plant) was found in no priming in BARI Gom-26.

The use of PEG in the seed priming method had increased the dry biomass. The dry biomass also increased in case of all wheat varieties incubation seeds at a temperature of $5^{\circ} \mathrm{C}$ and $\mathrm{GA}_{3}$ plant growth regulators. The use of dried wheat seeds in the control plots did not increase the dry biomass. Shad et al. (2010) who reported that priming of wheat seed in $\left(\mathrm{P}_{2} \mathrm{O}_{5}\right)$ enhanced day to emergence and increased dry matter (DM) production compared with non-primed (Control). Verma et al. (2006) reported that both fresh as well as one year old mung bean seeds were soaked in $\mathrm{CaCl}(2 \%)$ for $16-18 \mathrm{~h}$ recorded significant increase seedling dry weight and rapid and uniform field emergence compared to control. 
Effects of Osmotic, Thermal and Plant Growth Regulators

Table 3. Role of seed priming types on dry biomass (g/plant) of three wheat varieties

\begin{tabular}{lllll}
\hline Priming types & Seed priming & BARI Gom-24 & BARI Gom-25 & BARI Gom-26 \\
\hline & Control & $7.85 \pm 0.42 \mathrm{~b}$ & $9.48 \pm 0.50 \mathrm{~ns}$ & $7.96 \pm 0.40 \mathrm{~b}$ \\
& $\mathrm{NaCl}$ & $7.48 \pm 0.42 \mathrm{~b}$ & $10.33 \pm 0.50 \mathrm{~ns}$ & $8.41 \pm 0.40 \mathrm{~b}$ \\
Osmo-priming & $\mathrm{KNO}_{3}$ & $8.59 \pm 0.42 \mathrm{ab}$ & $9.56 \pm 0.50 \mathrm{~ns}$ & $9.88 \pm 0.40 \mathrm{a}$ \\
& $\mathrm{KH}_{2} \mathrm{PO}_{4}$ & $8.72 \pm 0.42 \mathrm{ab}$ & $9.49 \pm 0.50 \mathrm{~ns}$ & $9.77 \pm 0.40 \mathrm{a}$ \\
& $\mathrm{PEG}$ & $9.58 \pm 0.42 \mathrm{a}$ & $10.20 \pm 0.50 \mathrm{~ns}$ & $10.68 \pm 0.40 \mathrm{a}$ \\
\hline \multirow{5}{*}{ Thermo-priming } & $7.54 \pm 0.09 \mathrm{c}$ & $7.54 \pm 0.07 \mathrm{~b}$ & $8.20 \pm 0.07 \mathrm{bc}$ \\
& $\mathrm{Control}$ & $7.50 \pm 0.09 \mathrm{c}$ & $8.35 \pm 0.07 \mathrm{~b}$ & $8.11 \pm 0.07 \mathrm{c}$ \\
& $0^{\circ} \mathrm{C}$ & $8.68 \pm 0.09 \mathrm{a}$ & $9.11 \pm 0.09 \mathrm{c}$ & $8.29 \pm 0.05 \mathrm{~b}$ \\
& $5^{\circ} \mathrm{C}$ & $8.40 \pm 0.05 \mathrm{~b}$ & $8.35 \pm 0.07 \mathrm{a}$ & $8.35 \pm 0.07 \mathrm{a}$ \\
\hline & $10^{\circ} \mathrm{C}$ & $8.26 \pm 0.04 \mathrm{c}$ & $8.11 \pm 0.12 \mathrm{c}$ & $7.50 \pm 0.14 \mathrm{c}$ \\
& $\mathrm{Control}$ & $9.20 \pm 0.04 \mathrm{a}$ & $9.53 \pm 0.12 \mathrm{a}$ & $8.40 \pm 0.14 \mathrm{~b}$ \\
& $\mathrm{GA} 3$ & $8.40 \pm 0.14 \mathrm{~b}$ & $8.29 \pm 0.04 \mathrm{~b}$ & $9.20 \pm 0.04 \mathrm{a}$ \\
\hline
\end{tabular}

In a column, data are the mean values with standard error having different letters within six different treatments differ significantly as per LSD at 5\% level. Data was recorded at postharvest period.

\section{Grain weight $\left(\mathrm{g} / \mathrm{m}^{2}\right)$}

Osmo-priming hand influenced in terms of grain weight of three wheat varieties. The highest grain weight $\left(520 \mathrm{~g} / \mathrm{m}^{-2}\right)$ was recorded in $\mathrm{KNO}_{3}$ for BARI Gom-25 and in PEG for BARI Gom-26. On the other hand the lowest grain weight $\left(390 \mathrm{~g} / \mathrm{m}^{-2}\right)$ was found in conventional practices of BARI Gom-26 (Fig. 3). Different temperature $\left(0^{\circ} \mathrm{C}, 5^{\circ} \mathrm{C}\right.$ and $\left.10^{\circ} \mathrm{C}\right)$ had influence on grain weight of three wheat varieties. The highest grain weight $\left(550 \mathrm{~g} / \mathrm{m}^{-2}\right)$ was recorded in $10^{\circ} \mathrm{C}$ temperatures from BARI Gom-26 and the lowest grain weight (380 $\mathrm{g}^{\mathrm{m}} \mathrm{m}^{-2}$ ) was found in no priming in BARI Gom-26. PGR (plant growth regulators) priming material (BAP, GA had greatly influenced on grain weight of three wheat varieties. The highest grain weight $\left(460 \mathrm{~g} / \mathrm{m}^{-2}\right)$ was recorded in GA for BARI Gom-26 and the lowest grain weight $\left(400 \mathrm{~g} / \mathrm{m}^{-2}\right)$ was found in no priming in BARI Gom-24. 


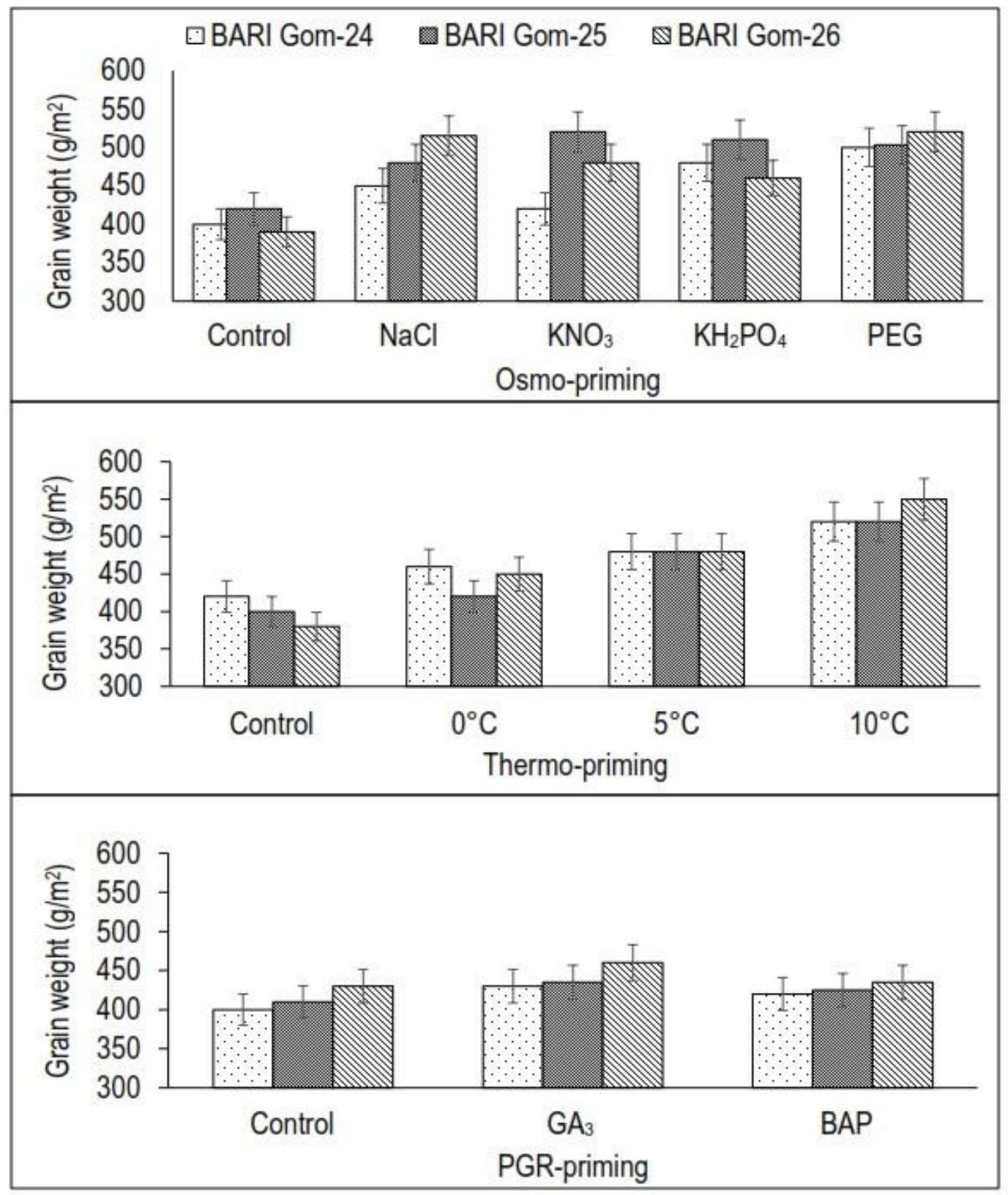

Fig. 3: Impression of priming types on grain weight $\left(\mathrm{g}^{\mathrm{m}} \mathrm{m}^{-2}\right)$ of three wheat varieties.

Seed priming had a huge role to increasing the weight of wheat seeds per square meter. Of the seed priming types used, osmo-priming showed the most significant response. The treatment did not received any type of priming did not show a significant increase in wheat seed weight gain. Primed crops grew more vigorously 
and yield higher. The researchers had recorded mean yield increases in six large series of on-farm trials from $5 \%$ to $36 \%$ (Harris et al. 2001). Seed priming with potassium salts (1\%) for $18 \mathrm{~h}$ increased wheat yield under dry land condition (Paul and Choudhury 1991). On-farm seed priming with water (hydro-priming) in maize, rice and chickpea showed that seed emergence faster, and yielded higher (Harris et al. 1999). The increase grain yield may be due to the fact that priming advances the metabolism which has a direct affect in increasing seed performance and hence yield (Varier et al. 2010).

\section{Conclusion}

The practice of seed priming improves the germination, vigor, and strong plant development of any crop at the field level. It is possible to get the desired crop yield if the seeds are inoculated using some commonly available seed priming agents. Overall due to the use of different priming agents, BARI Gom-24, BARI Gom25 and BARI Gom-26 varieties produced vigor saplings, faster shoot growth, maximum tiller number, increased dry biomass and better grain yield.

\section{References}

Aquila A and Taranto G (1986). Cell division and DNA synthesis during osmo-priming treatment and following germination in aged wheat embryos. Seed Sci. and Tech., 14: 333-341.

Bradford KJ (1986). Manipulation of seed water relations via osmotic priming to improve germination under stress conditions. Hort Sci., 21: 1105-1112.

Dollypan and Basu RN (1985). Mid-storage and pre-sowing seed treatments for lettuce and carrot. Scientia Hort., 33(6): 1026-1027.

Farooq M, Basra SMA, Hafeez-u-Rehman and Saleem BA (2008). Seed priming enhances the performance of late sown wheat (Triticum aestivum L.) by improving chilling tolerance. J. Agronomy and Crop Science, 194(1): 55-60.

Farooq M, Basra SMA, Saleem BA, Nafees M and Chishti SA (2005). Enhancement of tomato seed germination and seedling vigor by osmo-priming. Pak. J. Agri. S., 42(3): 36-41.

Gupta PC (1993). Seed vigour testing. In: Handbook of seed testing (Ed. Agrawal PK). DAC, Ministry of Agriculture, Govt. of India, New Delhi, pp. 242-249.

Harris D (1996). Effects of manure, genotype, seed priming, depth and date of sowing on the emergence and early growth of Sorghum bicolor (L.) Moench in semi-arid Botswana. Soil and Tillage Research, 40:73-88.

Harris D, Joshi A, Khan PA, Gothkar P, and Sodhi PS (1999). On-farm seed priming in semi-arid agriculture: development and evaluation in maize, rice and chickpea in India using participatory methods. Exp. Agric., 35: 15-29.

Harris D, Raghuwanshi BS, Gangwar JS and Singh SC (2001). Participatory evaluation by farmers of on-farm seed priming in wheat in India, Nepal and Pakistan. Exp. Agric., 37: 403-415.

Harris D, Tripathi RS and Joshi A (2000). On-farm seed priming to improve crop establishment and yield in direct-seeded rice, in IRRI: Inter. Workshop on Dry Seeded Rice Tech.

Heydecker W, Higgins J and Gulliver RL (1973). Accelerated germination by osmotic seed treatment. Nature (London), 246: 42-44.

Heydecker W, Higgins J and Turner YJ (1975). Invigoration of seeds. Seed Sci. and Technol., 3(3/4): 881-888.

Imranuddin, Arif M, Khan A, Sadiq M, Ahmad I, Ahmad N, Yazdan F, Zaman Q and Khan S (2016). Seed priming, nitrogen levels and moisture regimes affects phenology of wheat. European Academic Research, 6(4): 5563-5582. 
Kester ST, Geneve RL and Houtz RL (1997). Priming and accelerated ageing affect L-Isoaspartyl methyltransferase activity in tomato (Lycopersicon esculentum Mill.) seed. J. Exp. Bot., 48: 943-949.

Khan AA (1992). Preplant physiological conditioning. Hort. Rew., 13: 131-181.

Liu YA, Bino RJ, Vanderburg WJ, Groot SPC and Hilhorst HWM (1996). Effects of osmotic priming on dormancy and storability of tomato (Lycopersicon esculentum Mill.) seeds. Seed Sci. Res., 6: 49-55.

Paul SR and Chodhury AK (1991). Effect of seed priming with potassium salts on growth and yield of wheat under rainfed condition. Ann. Agric. Res., 12: 415-418.

Powell AA and Mathews S (1986). Cell membranes and seed leachate conductivity in relation to the quality of seeds for sowing. J. Seed Tech., 10: 81-100.

Rowse HR (1995). Drum priming -A non-osmotic method of priming seed. Seed Sci. Tec., 24: 281-294.

Shad KK, Shitab, Abdur R, Amir ZK, Khalil IH, Said W, Fida M, Shaheen N, Muhammad Z, Sajida P and Ahmad K (2010). Seed priming and phosphorus application enhance phenology and dry matter production of wheat. Pak. J. Bot., 42(3): 1849-1856.

Singh H, Jassal RK, Kang JS, Sandhu SS, Kang H and Grewal K (2015). Seed priming techniques in field crops - A review. Agri. Review, 36(4): 251-264.

Singh S and Bhan VM (1998). Response of wheat (Triticum aestivum) and associated weeds to irrigation regime, nitrogen and 2,4-D. Indian Journal of Agronomy, 43(4): 662-667.

Varier A, Vari AK and Dadlani M (2010). The subcellular basis of Seed Priming. Current Sci., 99(4): 450-456.

Verma SS, Punia RC and Dahiya OS (2006). Pre-sowing seed treatment for better crop establishment in mungbean. National Seed Seminar, Abstract XII ANGRAU, Hyderabad, pp. 145. 